\title{
Trade rules and exchange rate misalignments: in search for a WTO solution
}

\author{
VERA THORSTENSEN \\ EMERSON MARÇAL \\ LUCAS FERRAZ*
}

The debate on the link between trade rules and rules on exchange rates is raising the attention of experts on international trade law and economics. The main purpose of this paper is to analyze the impacts of exchange rate misalignments on tariffs as applied by the WTO - World Trade Organization. It is divided into five sections: the first one explains the methodology used to determine exchange rate misalignments and also presents its results for Brazil, U.S. and China; the second summarizes the methodology applied to calculate the impacts of exchange rate misalignments on the level of tariff protection through an exercise of "misalignment tariffication"; the third examines the effects of exchange rate variations on tariffs and their consequences for the multilateral trading system; the fourth one creates a methodology to estimate exchange rates against a currency of the World and a proposal to deal with persistent and significant misalignments related to trade rules. The conclusions are present in the last section.

Keywords: exchange rate; international trade; tariffs, IMF, WTO.

JEL Classification: F10; F13; F31.

\footnotetext{
* Vera Thorstensen, e-mail: vera.thorstensen@fgv.br, Emerson Marçal, e-mail: emerson.marcal@fgv.br, and Lucas Ferraz, e-mail: lucas.ferraz@fgv.br, are professors of the EESP-FGV and coordinators of the FGV Observatory on Exchange Rate. Submfitted: 28/May/2013; Approved: 19/September/2013. Daniel Ramos, Carolina Muller (lawyers), and Giovanni Merlin, Diogo Mendonça e Beatrice Zimmermann (economists) were research assistants. This paper is part of a broader research initiated in 2010 on the effects of misalignments on trade rules, whose first results were published in Thorstensen, V.; Marçal, E.; and Ferraz, L., "Impacts of Exchange Rates on International Trade Policy Instruments: The Case of Tariffs”, Journal of World Trade, vol. 46, issue. 3, 2012.
} 


\section{INTRODUCTION - A HISTORICAL OVERVIEW}

When the IMF and the GATT were created, during the 1940s, the exchange rate system was the gold-dollar standard. The GATT was designed to create rules towards the liberalization of trade while the IMF was established to supervise exchange rate policies and safeguard the balances of payment of its parts.

In this context, the IMF and the GATT created a direct dialogue linking exchange rate and trade through IMF Article IV and GATT Article XV.

IMF Article IV, iii) stated that "In particular, each member shall:

avoid manipulating exchange rates [...] in order to prevent effective balance of payments adjustment or to gain an unfair competitive advantage over other members;

GATT Article XV.4 established that:

contracting parties shall not, by exchange actions, frustrate the intent of the provisions of this Agreement, nor by trade action, the intent of the provisions of the Articles of Agreement of the IMF.

With the end of the gold-dollar standard in the 1970s, the IMF and the GATT tried to adapt their roles to a new world economic order. IMF focused into managing the stability of the international financial system, now including several exchange rate arrangement options: from pegged rates to completely floating ones.

GATT on the other hand was not able to negotiate new rules for trade that took into consideration this new reality. The only change, adopted by the Working Group on Exchange Rate, in 1980, was the Guidelines on Article II.6 of the GATT (L/4938) updating an existing process that allowed countries facing an exchange rate undervaluation of at least $20 \%$ to renegotiate their specific tariffs. This mechanism was invoked only 11 times and was forgotten in the archives of the WTO.

During the decades of the 1980s and the 1990s the majority of countries adopted exchange rate arrangements pegged to some of the main currencies. In periods of crisis, negotiations among some of the main economic powers were enough to bring the whole monetary system back to its equilibrium. The examples are the Louvre and the Plaza Agreements.

In the first decade of the 2000s, the international system witnessed an increasing liberalization of capital and a significant increase in trade flows. Exchange rate misalignments were quite frequent, as the examples of China and many of the ASEAN countries could show. The impacts of the financial crisis of 2008 in the U.S. and its spillover on other countries led governments to rely frequently on loosened monetary and exchange rate practices that deeply affects the main instruments of the international trading system.

However, neither the IMF has ever agreed to use its Article IV power to declare a country as a currency manipulator, nor have WTO members brought a member 
to the DSB - Dispute Settlement Body - to challenge it as a frustrator of other members' benefits under the trade system.

What is important to stress is that with the globalization of production and the increase of trade, the existence of currency misalignments starts to play a bigger role on trade and, as a consequence, misalignments are undermining seriously the rules of the international trading system. Even so, there has been no reaction at the WTO level. The assumption that the WTO is responsible only for trade issues and the IMF the guardian of exchange rate matters, as if there was no link between the two, is a denial to accept the evidence that exchange rates are deeply intertwined with trade.

Brazil presented a submission to the Working Group on Trade, Debt and Finance (WGTDF) in April 2011, suggesting a work program starting by an academic research on the relationship between exchange rates and international trade (WT/WGTDF/W/53). In September $20^{\text {th }}, 2011$, Brazil presented its second proposal, suggesting the examination of available tools and trade remedies that might allow countries to redress the effects of exchange rate misalignments (WT/ WGTDF/W/56).

The WTO Secretariat presented its Note on a Review of Economic Literature in September $2^{\text {th }}, 2011$ (WT/WGTDF/W/57), as mandated by the Working Group. It was an extensive research, but it only presented analysis that followed the rationale of the IMF. It does not speak "WTO language". It did not touch the issue of the impacts of exchange rate misalignment on WTO principles, rules and its instruments.

Brazil's third submission, of November 2012 (WT/WGTDF/W/68), brought up the discussion of the effects of exchange rate misalignments on such instruments as well as the possibility of exploring existing WTO rules to address such effects.

With the impasse of the Doha Round and the multiplication of preferential trade arrangements and now with the negotiation of "mega" free trade arrangements, it cannot be accepted that exchange rate misalignments is a matter exclusive to the IMF. There is no trade rules system that is immune to exchange rate misalignments. A WTO system without a link between trade and currency, more specifically, between WTO and IMF, is one deeply flawed and disconnected from economic reality.

The main purpose of this paper is to analyze the impacts of exchange rate misalignments on tariffs - one of the most traditional trade policy instruments, as applied by the WTO - World Trade Organization. It is divided into five sections: the first one explains the methodology used to determine exchange rate misalignments and also presents its results for Brazil, U.S. and China; the second summarizes the methodology applied to calculate the impacts of exchange rate misalignments on the level of tariff protection through an exercise of "misalignment tariffication"; the third examines the effects of exchange rate variations on tariffs and their consequences for the multilateral trading system; the fourth one proposes a methodology to estimate exchange rates against a currency of the World and a proposal to deal with persistent and significant misalignments related to trade rules. The conclusions are present in the last section. 


\section{METHODOLOGIES AND ESTIMATES ON EXCHANGE RATE MISALIGNMENTS}

The purpose of this section is to present the methodology developed by FGV to estimate exchange rate misalignments that later will be used to assess the impacts of exchange rate misalignments on tariffs and other trade policy instruments.

There are several models for calculating equilibrium exchange rates in the literature: the purchasing power parity; the equilibrium of the current account (savings and investments); the equilibrium of the stocks of net foreign assets and liabilities of a country; or the exchange rate based on the unit of labor costs. The most used one is the model developed by the IMF.

\section{Estimates from the IMF}

The Consultative Group on Exchange Rates (CGER) has been estimating exchange rate misalignment for many years and has developed a methodology based on the equilibrium of the current account. It presents its results in the Reports under IMF Article IV Surveillance Mechanism. After the reform of this Mechanism in 2011, the External Sector used this methodology to analyze exchange rate misalignments for each specific country but broadened the analysis to exam not only current account but also reserves, capital flows and external balance, and exam the impacts of this misalignments to the multilateral system. These results were published in the Pilot External Sector Report (6/2012 and 8/2013) that presents IMF estimates of exchange rate misalignments by bands. The values for 2013 are presented in Graphic 1 .

Graphic 1: Differences of Real Effective Exchange

Rates and those consistent with Fundamentals (\%)

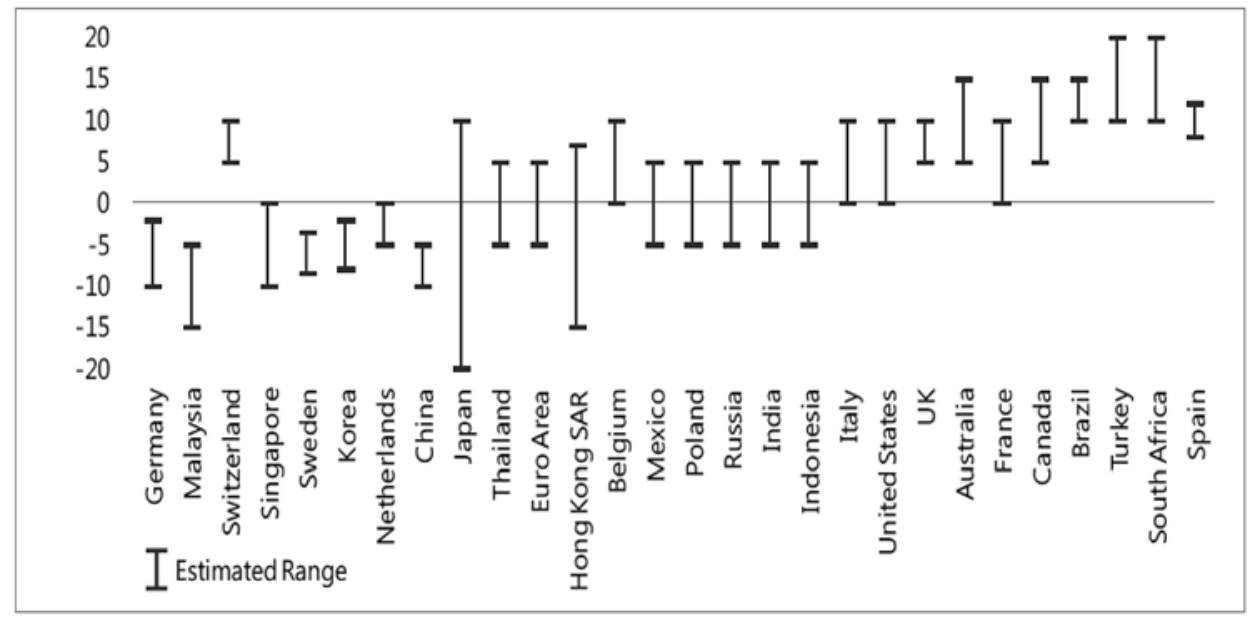

Source: IMF Pilot External Sector Report (August 2013). 


\section{Estimates from the Observatory on Exchange Rates from FGV — São Paulo}

The FGV - Observatory on Exchange Rate of the São Paulo School of Economics of Getulio Vargas Foundation has been calculating Brazil's exchange rate misalignments since 2009. It has developed a methodology to estimates real equilibrium exchange rate based on the stability of net foreign asset position of a country, by using an econometric model of cointegration.

Here were summarized the methodology, its underlying principles on fundamentals and its econometric methods. Finally, the estimates for Brazil, the U.S. and China exchange rate misalignments are presented. More details can be found in another paper of the authors in Thorstensen, Marçal and Ferraz (2012).

There is an important debate in the literature on the methodology and on which variables to use in the determination of the long run real exchange rate.

\section{A methodology to estimate misalignments}

The theoretical discussion on what are the variables behind the determination of long-run fundamentals is well known. An older literature dates back to the work of Edwards (1987) and Dornbusch (1976). The first analyzes on the so-called Economy of Misalignment, its causes and consequences, and the second is a classic model of flexible exchange rates where monetary policy shocks cause variations beyond the long run fundamentals (PPP — Purchasing Power Parity).

The works of Bilson (1979) and Mussa (1976) are also classics in the literature and include the so-called Monetary Approach to exchange rate. Under this approach, the exchange rate would be determined primarily due to the relative evolution of output and money supply across countries, assuming the continuous validity of purchasing power parity and uncovered interest parity (UIP), as well as a stable money demand in the countries. The work of Meese and Rogoff (1983) cast doubt on the explanatory power of this theory. Stein (1995) proposes the approach of the natural rate of exchange (NATREX). According to the author, the equilibrium exchange rate is the one that equals the level of savings to the level of investment generated by the economic fundamentals.

A more recent discussion in the misalignment literature is presented by Williamson (1994). The concept of equilibrium exchange rate is the one that allows the country to maintain a determined deficit or surplus (seen as sustainable) in the current account. This is the Fundamental Real Exchange Rate Approach - FRER. Another more recent reference to this approach is Cline (2008). Cline and Williamson are calculating FRERs for many countries and publishing the results site of the Peterson Institute. One problem with this approach has to do with the subjectivity included in choosing the target level of current accounts. Moreover, this kind of approach focuses exclusively on flows and not on stocks.

Faruqee (1995) tries to incorporate issues related to the evolution of stocks and builds an economic model which allows an interaction between flows and stocks. In this way, he shows that there must be a stable relationship between real exchange 
rate and net external position of liabilities between residents and nonresidents. This is the Behavioral Real Exchange Rate Approach - BRER. Alberola, Cervero et al. (1999) developed an empirical exercise to estimate exchange rate misalignment using fundamentals suggested by Faruqee. Kubota (2009) builds an economic model where the representative agent maximizes the inter-temporal consumption and accumulates capital. Under this model, the real exchange rate is also function of terms of trade, net external position, and relative productivity of tradable and non-tradable sectors. This is the approach used by FGV in its estimation of misalignments.

This methodology seeks to reduce the existing degree of subjectivity in the estimation of exchange rate misalignment by connecting the real exchange rate to a set of fundamentals obtained from some theoretical model and decompose the actual real exchange rate series and the fundamentals in transitory and permanent components, using time series econometric techniques.

A common criticism to empirical exercises that estimate exchange rate misalignment lies in the fact that the results are often mixed. Although partly true, this sort of criticism cannot be used generically. The analyst must show clearly what question is being answered and what is the purpose of the measure of misalignment: to analyze the deviation from a long-run equilibrium, or to avoid large imbalances in the balance of payments, for example.

Another important point concerns the ability of each model in which the measure is based on misalignment to predict the real exchange rate in the medium and long term. Only models that are able to anticipate the movements of medium and long term should be taken into account. Finally, a fascinating theoretical and empirical question is to focus in the analysis of the ability for each set of fundamentals advocated by different approaches to generate well-specified models from a statistical viewpoint.

The approach of the literature of exchange rate misalignment recognizes both empirical and theoretical limitations of the Purchasing Power Parity (PPP) methodology and uses an approach based on economic fundamentals. These fundamentals are derived from an economic model which takes into account the dynamics of current account and capital account in the calculations of the equilibrium exchange rate. The econometric model contains the following variables: net foreign investment position (NFA), terms of trade (ToT), and a productivity indicator amongst the producing sectors of tradable goods and non-tradable goods (BS). BS is a relative indicator measure of tradable and non-tradable productivity comparing the country to its trading patterns in order to correct the classical effect of the Balassa-Samuelson on real exchange rate.

With these variables, the equilibrium exchange rate of long-term is estimated. Deviations from this rate with the observed exchange rate are the exchange rate misalignments.

i) $R E R_{t}=$ fundamentals $_{t}+$ misalignment $t_{t}$

ii) fundamentals $s_{t}=f\left(N F A_{t}^{\text {equilibrium }}, T T_{t}^{\text {equilibrium }}, B S_{t}^{\text {equilibrium }}\right)$ 
The real exchange rate of long-run equilibrium can be estimated from a time series econometric model that aims to estimate the structure given by $\mathrm{i}$ and ii.

The estimation is made by the decomposition of the series in transitory and permanent components, after an analysis of stationarity and cointegration (Engle \& Granger, (1987); Johansen, (1995); \& Gonzalo and Granger, (1995). The transitory component is connected to the misalignment and the permanent component is connected to the long run equilibrium. The economic series individually analyzed, in general, do not tend to revert to some level of long run position due to nonstationarity. In a technical way, the economic series are integrated, i.e., shocks are accumulating over time. The series are said to be cointegrated if shocks accumulate in a common set of series, in such a way that there is a linear combination between them, with a stationary property. Thus, two cointegrated series can drift away only in the short-run, but tend to revert to its long-run equilibrium. The real exchange rate can move away from certain series called fundamentals, but if they are indeed a long-run determinant of the exchange rate, then the series will revert to its long-run equilibrium.

\section{Results}

The FGV Observatory on Exchange Rate has been estimating G20 exchange rate misalignments. The estimations for Brazil, the U.S. and China's real equilibrium exchange rate, using cointegration techniques are here presented. The econometric model contains the series of fundamentals listed above. The results are as follows:

\section{Estimates for Brazil}

Graphic 2 shows the evolution of the level of misalignment observed in the Brazilian economy from 1980 to 6/2013. The highest negative misalignment level occurred in 2003, with the exchange rate being lower than $20 \%$ below equilibrium. The first stage is associated with the macroeconomic stabilization of the Brazilian economy in which the exchange was not floating. The second period concerns the effects of the crisis of confidence in the transition from President Cardoso to President Lula. The graphic also suggests that an exchange rate misalignment has a high degree of persistence. Periods of positive misalignments tend to be followed by other periods of positive misalignment and the same goes for negative values.

The line of fundamentals, which denotes the value of long-run equilibrium to which the real exchange rate should converge, shows that in the 1990s there was a trend of worsening of fundamentals that was halted and reversed during the year 2000. In recent years the real exchange rate presents a strong appreciation.

Estimating the real equilibrium exchange rate is a complex task and raises long discussions. The estimates are subject to the customary caution, especially for periods at the end of the sample, in which all the developments of recent events have not been fully expressed in the series, which can distort the estimate in some un- 
known way. The model estimated here suggests that the Brazilian exchange rate has been overvalued since 2009 and the misalignment was growing till 2011. It is estimated that in 2011 the exchange rate was higher than 30\% above the equilibrium. Measures taken by the Government in March 2012 brought the misalignment to around $20 \%$ at the end of 2012, and almost to equilibrium in July 2013.

\section{Graphic 2: Brazil Real Exchange Rate, Fundamentals and Exchange Rate Misalignments (6/2013)}
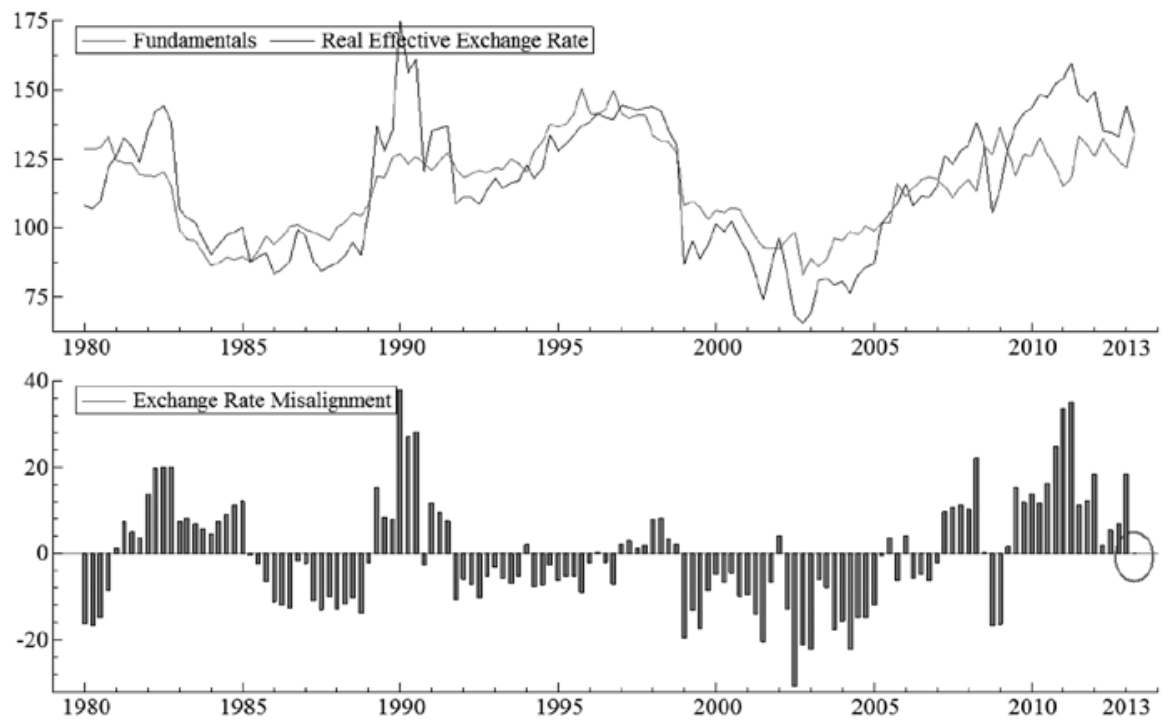

Source: Observatory on Exchange Rate (2013).

\section{Estimates for the United States}

The evolution of the level of misalignment observed in the U.S. economy from 1970 to July 2013 is presented in Graphic 3. The estimates of exchange rate misalignments suggest three moments of overvaluation of the dollar. The first occurred in the first half of the 1970s. The second stage began in the mid-1980s, the third lasted until the first half of the years 2000 . The line of fundamentals, which denotes the value of long-run equilibrium to which the exchange rate should converge, shows a continuing trend of worsening fundamentals of the U.S. economy.

The model suggests that the U.S. exchange rate has been below its equilibrium in the period from 2005 till 2012, except for 2009. The values were not as high as the ones observed in other periods, but were between $-5 \%$ and $-7 \%$ depending on the year under analysis. In 2011 the estimated undervaluation was around $-7 \%$ and by the end of 2012 it was around $-2 \%$. In 2013 it reaches its equilibrium and in July 2013 it was around $+2 \%$. 

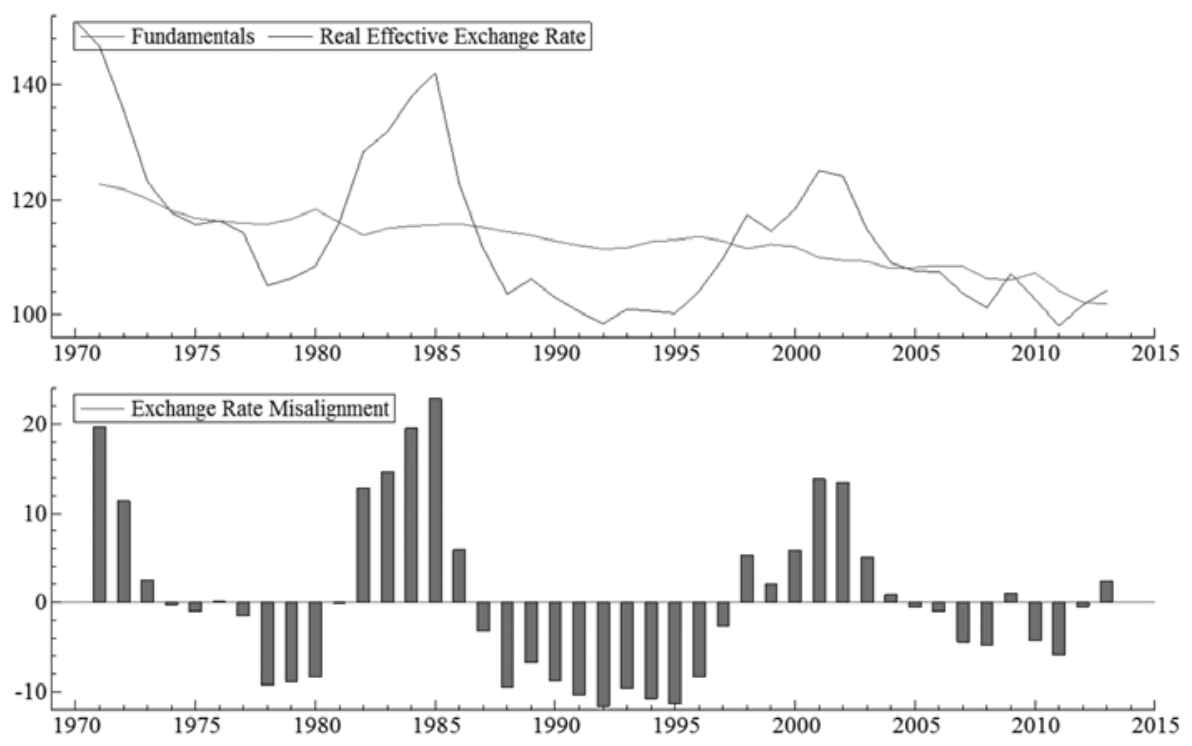

Source: Observatory on Exchange Rate (2013)

\section{Estimates for China}

The evolution of the level of misalignment observed in China economy from 1985 to 2012 is presented in Graphic 4. The macroeconomic variables necessary to calculate China's misalignment for July 2013 are yet not available.

The analysis shows the determinants of Chinese real exchange rate in this period using cointegration techniques and the data set that contains real exchange rate (RER), net foreign asset position (NFA), the level of international official reserves as percentage of gross domestic product (RGDP) and difference of gross per capita income between China and their main trading patterns (DiffPercapita). The introduction of reserves in the Vector Error Correction Model is not the usual practice in the literature. In this paper, with the inclusion of official reserves, evidence was obtained in favor of cointegration hypothesis among these variables. Whereas the traditional model without official reserves does not give evidence in favor of cointegration. The variables NFA, RGDP and DiffPercapita can be seen as long run determinants of real exchange rate. From the model it is possible to estimate the level of Chinese exchange rate misalignment. 
The model suggests that the Chinese exchange rate has been below its equilibrium since 2000. In 2011 and 2012 the estimated undervaluation was around $-15 \%$.

\section{Graphic 4: China Real Exchange Rate, Fundamentals and Exchange Rate Misalignments}
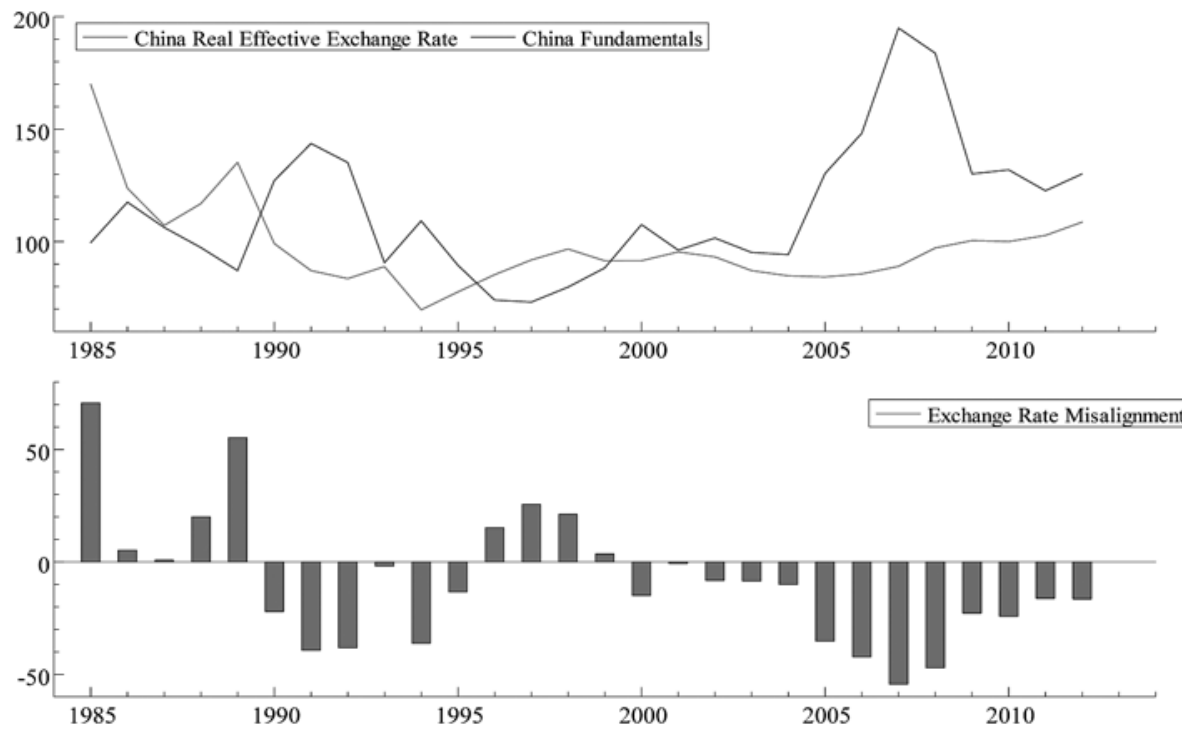

Source: Observatory on Exchange rate (2013).

In summary, it is possible to estimate exchange rate misalignment following the methodology based on the analysis of long-term fundamentals of the real exchange rate using a Vector Autoregressive Model with Error Connection Term as econometric model. It has used as fundamentals the net foreign investment position, terms of trade and an indicator of difference in productivity in the sectors of tradable and non-tradable goods. There is theoretical justification for such choice, and the relationship between real exchange rate and these variables is empirically validated as shown by Faruqee, H. (1995), Alberola, E., S. Cervero, H. Lopez and A. Ubid (1999) and Kubota, M. (2009).

The FGV Observatory has been calculating misalignments of several countries. The results for the end of 2012 are presented in Graphic 5. 


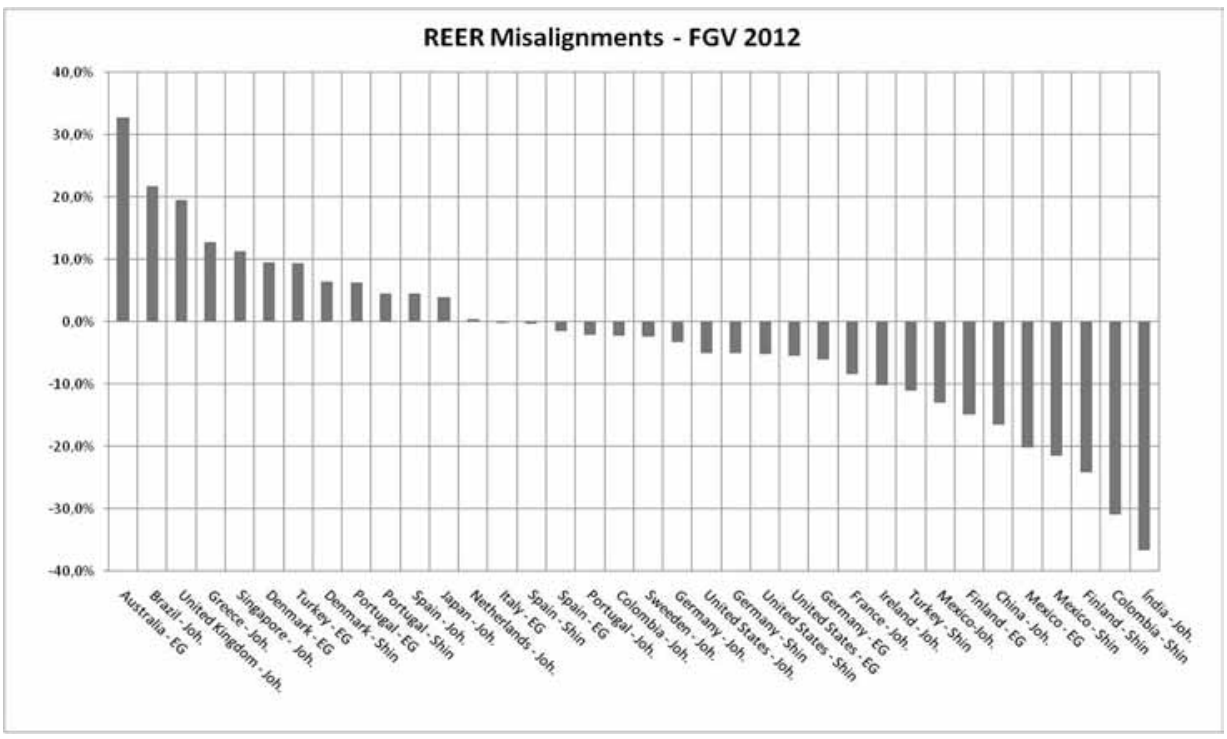

Source: Observatory on Exchange Rate (2013).

\section{Some conclusions}

There is an important literature presenting different methodologies and sophisticated econometric models to estimate countries' exchange rate misalignments.

When comparing the results, some conclusions can be reached: i) each methodology is focused in a different economic aggregate and so produce different results; ii) for many countries the results point consistently to the overvaluation or undervaluation of these countries' exchange rates in significant values and for extended periods of times. The relevant point here is to discuss which methodology produces the more robust results for the purpose of examining their effects on trade rules (WTO) or on financial rules (IMF). Due to the present situation of widespread misalignments, this debate is becoming inevitable and urgent.

\section{WTO AND THE EFFECTS OF EXCHANGE RATE MISALIGNMENTS ON TARIFFS}

The next question to be raised is how such misalignments affect the international trading system built by the GATT and WTO over the last 70 years.

Tariffs are GATT's historical instrument for trade protection and one of the main negotiating subjects included in multilateral rounds. Its purpose is to allow an objective and transparent protection for goods, and to be reduced over time, as a result of trade liberalization.

An important picture of each WTO member tariff protection can be given by a 
graphic showing tariff averages for each chapter of the Harmonized Commodity Description and Coding System - HS (97 chapters), which includes: foodstuff, mineral, textiles, machines, electronics, vehicles and aircrafts, among others.

The concepts of tariff and tariffication of non-ad valorem barriers is a basic instrument for trade negotiation in the WTO. A common approach is to estimate the ad valorem equivalent rates of several duties expressed on a monetary basis, such as specific rate duties and variable levies. The instruments of trade defense as anti-dumping, countervailing measures and safeguards can also be considered as equivalent to tariffs. According to this logic, exchange rate misalignments can also be tariffied through the calculation of a tariff equivalent. Just like tariffs, the effect of the exchange rate can be transferred into imported and exported goods' prices.

FGV developed a methodology to estimate the implicit tariff dimension behind exchange rate misalignments. A summary of the methodology is presented below. More details can be seen in Thorstensen, Marçal, and Ferraz (2012).

\section{The tariffication exercise}

The objective is to tariffy the exchange rate misalignments and to estimate the impact of the misalignment on the level of the tariff protection, a kind of a tariffication exercise. The first step is to express local import prices as a function of international prices, equilibrium exchange rates and tariff barriers.

In a given bilateral trade relationship, equilibrium domestic import prices can be generally decomposed into equilibrium international prices, equilibrium exchange rates and tariff barriers, as in equation (1):

$$
\mathrm{P}_{\mathrm{imp}}^{\mathrm{dom}}=\mathrm{P}_{\mathrm{exp}}^{*} \cdot \Theta_{\text {dom }}(1+\mathrm{t})
$$

Where,

$\mathrm{P}_{\mathrm{imp}}^{\mathrm{dom}}$ : domestic price of the good imported, expressed in local domestic currency;

$\mathrm{P}_{\exp }^{*}$ : international price of the good exported by the foreign economy;

$\Theta_{\mathrm{dom}}$ : nominal exchange rate in the domestic economy;

$(1+t)$ : tariff barrier (tariff effect).

Regarding the foreign economy, its international export price $\left(\mathrm{P}_{\text {exp }}^{*}\right)$ can be decomposed as in equation (2):

$$
\mathrm{P}_{\exp }^{*}=\mathrm{P}_{\mathrm{dom}}^{*} \cdot \frac{1}{\Theta^{*}}
$$

Where,

$\mathrm{P}_{\mathrm{dom}}^{*}$ : foreign price of the good exported by the foreign economy, expressed in local foreign currency; 
$\Theta^{*}$ : nominal exchange rate in the foreign economy.

Therefore, equation (1) can be rewritten as in (3):

$$
\mathrm{P}_{\mathrm{imp}}^{\mathrm{dom}}=\mathrm{P}_{\mathrm{dom}}^{*} \cdot \frac{1}{\Theta^{*}} \cdot \Theta_{\mathrm{dom}}(1+\mathrm{t})
$$

The impact of possible exchange rate misalignments on import domestic prices can be estimated by first taking logs in both sides of equation (3) and then linearizing it. This procedure allows equation (3) to be expressed in percentage form, according to equation (4) below:

$$
\frac{d\left(P_{\text {imp }}^{\text {dom }}\right)}{P_{\text {imp }}^{\text {dom }}}=\frac{d\left(P_{\text {dom }}^{*}\right)}{P_{\text {dom }}^{*}}-\frac{d\left(\Theta^{*}\right)}{\Theta^{*}}+\frac{d\left(\Theta_{\text {dom }}\right)}{\Theta_{\text {dom }}}+\frac{d(1+t)}{1+t}
$$

Assuming the price of the foreign good $\mathrm{P}_{\mathrm{dom}}^{*}$ (expressed in local foreign currency) to be less sensitive to exchange rate misalignments (e.g., low import content or existence of government import subsidies), equation (4) can be rewritten as:

$$
\frac{d\left(P_{\text {imp }}^{\text {dom }}\right)}{P_{\text {imp }}^{\text {dom }}}=-\frac{d\left(\Theta^{*}\right)}{\Theta^{*}}+\frac{d\left(\Theta_{\text {dom }}\right)}{\Theta_{\text {dom }}}
$$

According to equation (5) local price fluctuations of the goods imported by the domestic economy can be described by exchange rate misalignments, both in the domestic economy as well as in the foreign economy. As noted in equation (5), foreign currency devaluations contribute to the increased competitiveness of the good imported by the domestic economy, making it cheaper (because $\left.\left(\mathrm{d}\left(\Theta^{*}\right) / \Theta^{*}\right) \geq 0\right)$. The same reasoning applies to domestic currency valuations (because $\left.\left(\mathrm{d}\left(\Theta_{\mathrm{dom}}\right) / \Theta_{\mathrm{dom}}\right) \leq 0\right)$.

For the calculation of an import tariff adjusted to exchange rate misalignments (percentage) as described in (5), it is possible to rewrite equation (3) in the form of deviations from the equilibrium exchange rates. For instance, in the case where the exporting foreign economy manipulates its exchange rate so as to make its exports more competitive (devaluation) and the importing domestic economy operates with an overvalued exchange rate, equation (3) can be rewritten with the following adjustments in the rates of equilibrium:

$$
\left(1+\left(-\frac{d\left(\Theta^{*}\right)}{\Theta^{*}}+\frac{d\left(\Theta_{\text {dom }}\right)}{\Theta_{\text {dom }}}\right)\right) \cdot P_{\text {imp }}^{\text {dom }}=P_{\text {dom }}^{*} \cdot \frac{1}{\Theta^{*}} \cdot \Theta_{\text {dom }}(1+\mathrm{t}) \cdot\left(1+\left(-\frac{d\left(\Theta^{*}\right)}{\Theta^{*}}+\frac{d\left(\Theta_{\text {dom }}\right)}{\Theta_{\text {dom }}}\right)\right) .
$$

So, it is possible to define an import tariff adjusted for currency fluctuations, as follows:

$$
(1+\mathrm{t}) \cdot\left(1+\left(-\frac{\mathrm{d}\left(\Theta^{*}\right)}{\Theta^{*}}+\frac{\mathrm{d}\left(\Theta_{\mathrm{dom}}\right)}{\Theta_{\text {dom }}}\right)=\left(1+\mathrm{t}^{\text {ajust }}\right)\right.
$$


Therefore, in order to take into account possible exchange rate misalignments in relation to their equilibrium values, the so called adjusted tariff can be calculated as in (7):

$$
t^{\text {adjust }}=\left(-\frac{d\left(\Theta^{*}\right)}{\Theta^{*}}+\frac{d\left(\Theta_{\text {dom }}\right)}{\Theta_{\text {dom }}}\right)+t .\left(1+\left(-\frac{d\left(\Theta^{*}\right)}{\Theta^{*}}+\frac{d\left(\Theta_{\text {dom }}\right)}{\Theta_{\text {dom }}}\right)\right)
$$

It is worthy of note that equation (7) required some important simplifying assumptions along its estimation path. Firstly, foreign prices (expressed in foreign local currency) were considered to be constant even under foreign exchange rate misalignments. Secondly, the empirically estimated exchange rate misalignments values used in this study were multilateral in nature. That, in principle, could make a difference in value, if only bilateral misalignments were considered. Lastly, the methodology developed in this section disregards possible crossing effects among different sectors in the economy as a result of real exchange rate fluctuations. In other words, it takes a partial equilibrium approach to a problem that is very likely to be a general equilibrium problem in nature.

Also, it focuses only on the import side of the problem. A more comprehensive analysis should shed some light on other channels through which the domestic economy could also be hurt by competitive foreign exchange rate misalignments. For instance, it is very likely that the market-share of domestic exports can be also negatively affected by competitive devaluations carried out in economies that compete with it in international markets.

The general equilibrium nature of real exchange rate misalignments and the capture of their tariff dimension is already included in this project and will be tackled in future research. Therefore, the exercise here should be better taken as a short-run partial approach to the problem.

\section{Impacts of exchange rate misalignments on the tariffs levels}

Some simulations can be developed based on the estimates of exchange rate misalignments and its tariff equivalents, obtained through the tariffication of exchange rates.

It is important to stress that the objective of this research is not the search for a precise value for the misalignments, but only a threshold beyond which trade policy instruments become ineffective. It will be for the WTO members to negotiate not only the best methodology to use but also the level of misalignment above which an instrument should be negotiated to neutralize the effects of exchange rate on trade and to regain the effectiveness of its instruments and other GATT/WTO rules negotiated throughout the years.

This paper explores a few hypotheses, using approximated values for misalignments calculated by the FGV Observatory at the end of 2012. The members examined are: the U.S. $(-5 \%)$ and China $(-17 \%)$ as examples of undervalued currencies and Brazil $(+20 \%)$ as an example of an overvalued currency. This approach can be easily expanded for all WTO members. 
The values of tariffs - bound and applied ones - were obtained in the WTO database (Tariff Analysis Online) and dated from 2008 to 2010. A comparison is presented using simple averages of bound and applied tariffs at HS 2 digits.

The effects of tariffied exchange rates can be estimated by the variation of both bound and applied average tariffs for these countries through the tariffication exercise. The results of the simulations for 2012 showed that the effects of exchange rate misalignments on tariff averages are considerable. The results are presented to the U.S., China and Brazil.

\section{Effects of exchange rates on US' tariffs}

The U.S.' average bound and applied tariffs present close values, and vary from $0 \%$ to $+13 \%$ (except HS Chapter 24 - tobacco, which average is around $140 \%$ )

i) Considering a devaluation of $5 \%$ in the U.S.' exchange rate:

The effect of a $5 \%$ exchange rate devaluation on tariffs currently varying from $0 \%$ to $+13 \%$, will result in tariffs varying from $+5 \%$ to $+19 \%$. Therefore, tariffs will become well above the bound values negotiated by the U.S. at the WTO (Graphic 6).

\section{Graphic 6: Impacts of US Exchange Rate Misalignment on US Bound and Applied Tariffs (2012)}

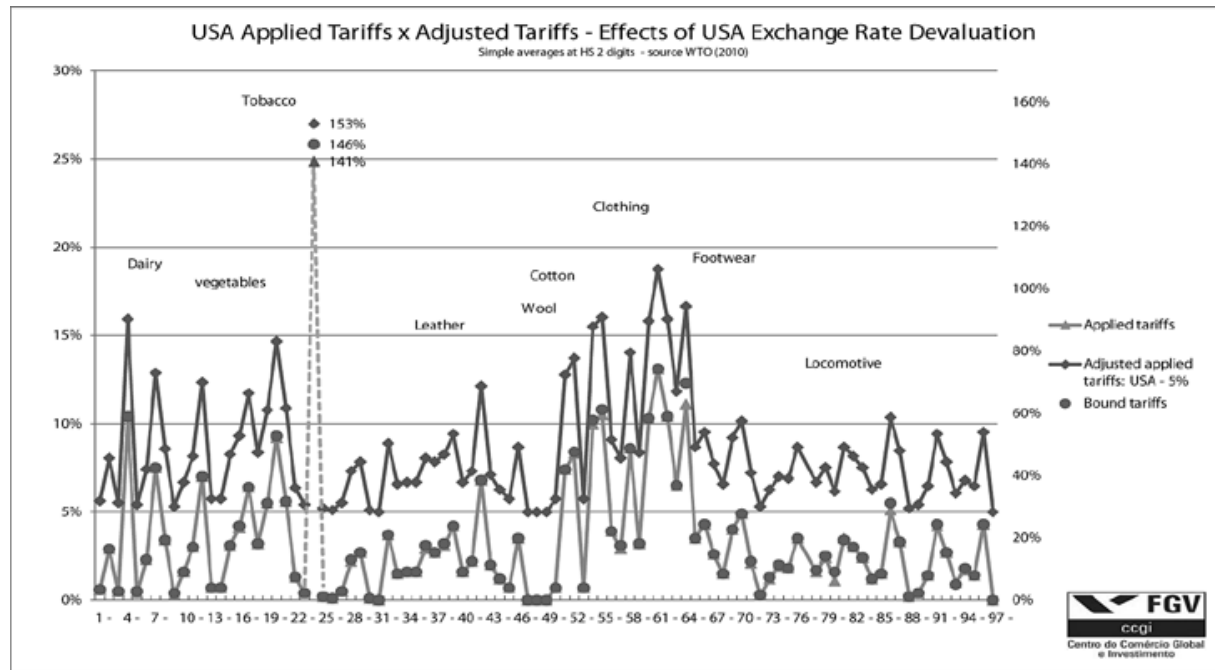

Source: Observatory on Exchange rate (2013).

The devaluation of the exchange rate not only represents a stimulus to the exports from countries with devalued currencies, but also creates an extra-tariff to other countries' imports. Due to the fact that bound and applied rates are almost at the same level for the U.S., the adjusted tariffs became values well above the WTO's bound tariffs.

One could question whether the US is not violating the WTO's rules, especially 
GATT Article II, which establishes that the contracting parties shall not apply tariffs in excess to the bound tariffs.

ii) To consider the effects of the undervaluation of the U.S. with other countries, one can combine the U.S. with undervalued and overvalued countries. For example: China with an undervaluation of $-17 \%$ and other overvalued countries like the United Kingdom $+25 \%$ and Brazil $+20 \%$ (Graphic 7 ):

- The effect of China's $17 \%$ exchange rate devaluation, combined with U.S.' devaluation, will result in U.S. tariffs varying from $-12 \%$ to $0 \%$.

- The effect of UK exchange rate overvaluation of $25 \%$, combined with U.S.' devaluation, will result in U.S. tariffs varying from $+30 \%$ to $+47 \%$.

- The effect of Brazil overvaluation of $20 \%$, combined with U.S.' devaluation, will result in U.S. tariffs varying from $+25 \%$ to $+41 \%$.

Graphic 7: Impacts of Exchange Rate Misalignments on U.S. Tariff Profile (2012)

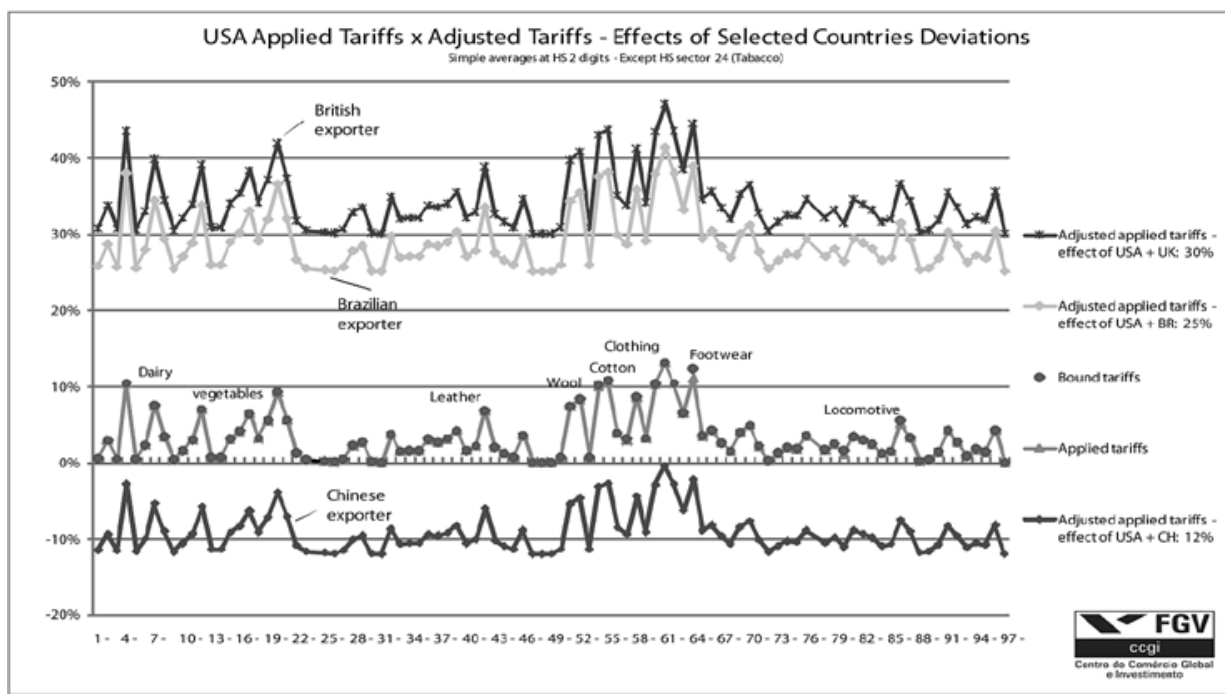

Source: Observatory on Exchange Rate (2013).

In summary, the undervaluation of the U.S. when combined with the undervaluation or the overvaluation of other countries represents a serious danger to one of the main principles of GATT and WTO, the most favorable nation principle, by which members must apply the same tariff to each member of the Organization (GATT Article I).

\section{Effects of exchange rates on China's tariffs}

China's average bound and applied tariffs, in the double-digit HS, also present close values, and vary from $0 \%$ to $+33 \%$.

i) Considering a devaluation of $17 \%$ in China's exchange rate: 
- Those tariffs currently varying from $0 \%$ to $+33 \%$, will vary from $+17 \%$ to $+53 \%$. Therefore, these tariffs are also well above the bound values negotiated by China at the WTO.

As in the U.S. case, the devaluation of the exchange rate not only represents a stimulus to the exports from countries with devalued currencies, but also creates an extra-tariff to other countries' imports. Due to the fact that bound and applied rates are almost the same for China, the adjusted tariffs became values well above the WTO's bound tariffs. This could, again, raise questions on the violation of GATT Article II.

ii) Considering the effect of the undervaluation of China with the misalignments of other countries, one can combine the undervaluation of the US $(-5 \%)$ with Mexico $(-20 \%)$ and with the overvaluation of Brazil (Graphic 8):

- The effect of the US $5 \%$ exchange rate devaluation will result in China's tariffs varying from $+12 \%$ to $+48 \%$.

- The effect of Mexico 20\% exchange rate devaluation will result in China's tariffs varying from $-3 \%$ to $+27 \%$.

- The effect of Brazil overvaluation of $20 \%$ will result in China's tariffs varying from $+37 \%$ to $+79 \%$.

Graphic 8: Impacts of Several Exchange Rate Misalignments on China Tariff Profile (2012)

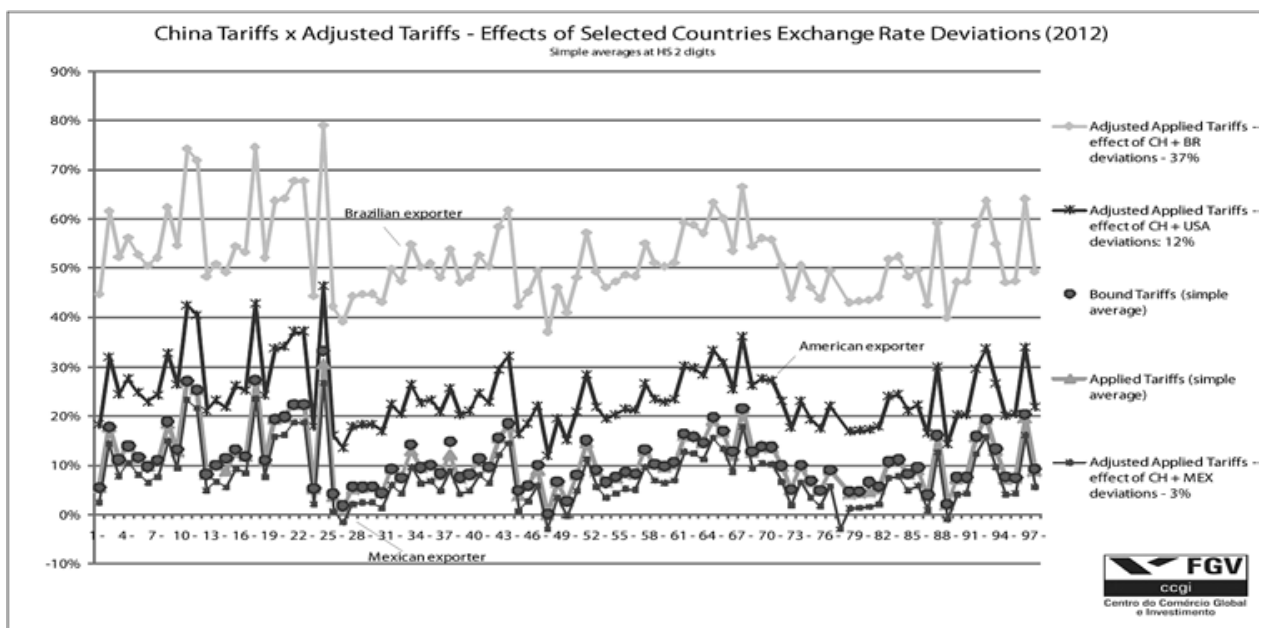

Source: Observatory on Exchange rate (2013).

In summary, as shown in the U.S. case, the devaluation of China's also endangers the most favored nation principle.

\section{Effects of exchange rates on Brazil's tariffs}

i) For a $20 \%$ overvaluation of Brazil's exchange rate, the results are the following (Graphic 9): 
- The average bound tariffs of Brazil, which currently vary from $+12 \%$ to $+50 \%$, with an overvaluation of $+20 \%$ will vary from $-11 \%$ to $+19 \%$.

- The average applied tariffs of Brazil, which currently vary from $0 \%$ to $+35 \%$ due to its exchange rate overvaluation will vary from $-20 \%$ to $+8 \%$.

Graphic 9: Impacts of Brazil Exchange Rate Misalignement on Brazil Tariff Profile (2012)

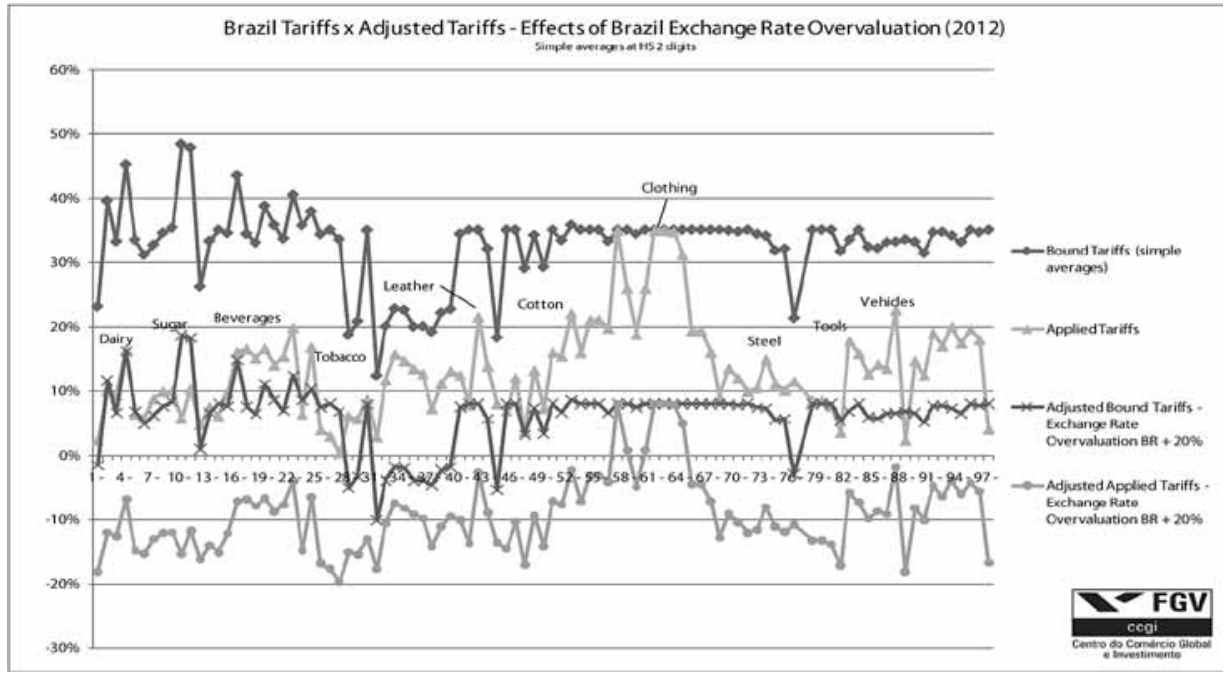

Source: Observatory on Exchange rate (2013).

An exchange rate overvaluation of $+20 \%$, represents not only a reduction of Brazil's bound tariffs but actually reduces applied tariffs to negative levels, becoming an incentive to imports.

In this scenario, it becomes easier to understand the reluctance of some sectors to accept any significant cut on bound tariffs, as it has been negotiated in the Doha Round. The same observation can be made in the context of negotiations in preferential trade agreements.

ii) Adding the effects of a 5\% devaluation for the U.S.' exchange rate, Brazil's average applied tariffs will vary from $-25 \%$ to $+2 \%$.

iii) Adding the effects of a $17 \%$ devaluation for China's exchange rate, Brazil's average applied tariffs will vary from $-35 \%$ to $-15 \%$.

iv) Adding the effects of a $20 \%$ devaluation for Mexico's exchange rate Brazil's average applied tariffs will vary from $-40 \%$ to $-19 \%$.

iii) Adding the effects of a $25 \%$ overvaluation for UK's exchange rate, Brazil's average applied tariffs will vary from $+5,5 \%$ to $+42 \%$.

In summary, the U.S.', China's and Mexico's exchange rate devaluations, which represent a subsidy to their exports, not only reduced Brazil's negotiated bound tariffs, but also transformed Brazil's applied tariffs into a stimulus to U.S.' and China's imports. On the other hand, the overvaluation of UK's exchange rate, as it is higher than Brazil's own overvaluation, slightly enhances Brazil's applied tariffs. 


\section{Some conclusions}

In conclusion, the coexistence of two different exchange rate misalignments, one for overvalued countries and other for undervalued countries when significant and applied for extended periods of time, represents a serious distortion for many international trade instruments, especially for tariffs, which are essential for efficient rules and practices.

The possible simulations of the effects of exchange rate misalignments on countries' tariffs are limitless since each country will have a different set of adjusted tariffs for each bilateral trade relationship, considering both countries deviations. The problem is, thus, systemic, affecting potentially every contracting party, with different degrees of distortions. These distortions will be greater where the difference between each country's exchange rate deviation is wider. The consequences of competitive exchange undervaluation demonstrate the potential for a "race to the bottom" among WTO members.

With the progressive tariff rate reduction throughout the negotiation rounds, and due to the high level of exchange rate misalignments maintained by several important countries, the exchange rate misalignments end up having a greater relevance than tariffs themselves. Although being present in some articles of the GATT and in some agreements of the WTO, the effects of exchange rate misalignments on trade regulation were never taken into consideration, institutionally, by its members. The main GATT article to foresee the effect of exchange rates, Article XV.4 has never been tested neither by the GATT nor by the WTO dispute settlement bodies.

However, the misalignments of exchange rates have significant impacts on the application of trade principles and instruments: it can affect market access concessions. They can affect the balance of tariff negotiation achieved through several multilateral trade rounds. Their effects on tariffs can represent commercial advantage gains for countries with devalued currencies and can bring unpredictability to the multilateral trading system.

\section{A PROPOSAL TO ADDRESS THE EFFECTS OF MISALIGNMENTS ON TRADE}

There are already some proposals in discussion to deal with significant and persistent exchange rate misalignments.

One approach is to look for the "manipulators" of exchange rates. This proposal tries to develop a methodology based on IMF Article IV concept of exchange rate manipulation and analyses the magnitude of reserves, current account and currency misalignments. This approach is presented in the work of Joseph Gagnon from the Peterson Institute in Washington, Combating Widespread Currency Manipulation, (PB12-19). More recently, Fred Bergsten and Joseph Gagnon published another article (Bergsten, 2012) in which they name Switzerland, Japan, Israel, 
Singapore, China, Malaysia, Thailand, and oil exporters as currency manipulators. This analysis is done following the rationale of the IMF.

The problem with this approach is that it relies on the political will and strength of the IMF to identify a member as a currency manipulator, a very sensitive political issue. Furthermore, as some authors have argued ${ }^{1}$, the way IMF's Article IV is presently drafted, it is really difficult to prove the intent of a member in manipulating its currency in order to gain a "competitive advantage", especially taking into account the new role of the IMF and its surveillance mechanism. Finally, even if the IMF were to recognize a member as a currency manipulator, it lacks a dispute settlement mechanism or strong remedies to force a member to change its exchange rate policy.

Another possible approach is to look for the "frustrators" of trade objectives. This proposal tries to develop a methodology based on GATT Article XV concept of frustration of trade objectives contained in GATT provisions, that is, the benefits of trade under a set of negotiated rules. This proposed methodology follows the logic of the GATT and is to be implemented and managed by the WTO.

One important difference between the two approaches is that while the first seeks to define what a currency manipulation is, and who are the "guilty countries", the second approach focuses on the consequences to trade of a wide range of currency-related public policies that are frustrating the objectives of the WTO. In this sense, it does not seek to identify currency manipulators, but to tackle the damaging effects of exchange rate misalignments on trade, that is the frustration effect ${ }^{2}$.

\section{The proposal}

In order to identify when a country would be frustrating trade objectives through exchange rate misalignments, firstly the period of time after which the misalignment sufficiently impacts these objectives must be determined. The GATT Guidelines on Article II.6 of the GATT (L/4938) established that 6 months of exchange rate misalignment would be enough to allow for the renegotiation of the specific import tariffs of a member. One could arguably use this as the relevant lapse of time during which a currency is misaligned in order to seek redress at the WTO level.

The second important issue would be to determine the level of exchange rate misalignment beyond which trade objectives are being frustrated. GATT Article II.6 considered that the misalignment should reach at least $20 \%$ before a tariff renegotiation could be asked. One must take into consideration, however that, at the time, import tariffs were, in average, much higher than they are today, and, thus, less sensitive to

\footnotetext{
${ }^{1}$ See Zimmermann, Claus D. "Exchange Rate Misalignment and International Law”, vol. 105(3) AM. J. INT'L L., 2011, pp. 427-437; Fudge, Nathan, "Walter Mitty and the Dragon: An Analysis of the Possibility for WTO or IMF Action against China's Manipulation of the Yuan", Journal of World Trade 45, No. 2, 2011, pp. 349-373 and Irwin, Douglas A., "Sprit de Currency", Finance and Development, vol. 48, No.2, IMF, June 2011.

${ }^{2}$ This issue was subject of a deeply resourceful discussion held at the Institute of International Economic Law (IIEL) Fellows Lunch meeting at Georgetown University, last January. The authors would like to thank all the participants, and especially Prof. Michael Gadbaw, for the invaluable insights.
} 
exchange rate misalignments. WTO members would thus need to negotiate a new threshold, possibly significantly lower than the $20 \%$ indicated in the guidelines. Our proposal is $10 \%$ for developed countries and $15 \%$ for developing ones.

Finally, in order to determine the degrees of misalignment, the proposal here explored is based on the negotiation among WTO members of a band for the fluctuation of exchanges rates within set limits. The steps are the following:

1 - Creation of a WTO virtual trade currency - the World Currency (WC) based on the weighted average trade of goods and services from more than $85 \%$ of international trade. IMF has its own virtual currency, the SDRs - Special Drawing Rights based on four currencies weighted by the trade on goods and services and also reserves from: dollar, euro, pounds and yen.

2 - Estimation of the time series of exchange rate oscillations for the main trading partners against this WTO currency (WC).

3 - Negotiation of a band or target zone for allowable fluctuation. Example: from $-10 \%$ to $+10 \%$ for developed countries with low tariffs and from $-15 \%$ to $+15 \%$ for developing countries with high tariffs.

4 - Each member would be free to choose the exchange rate arrangement that best fits its economic policy, which shall continue to be overseen by the IMF. Each member can allow fluctuation of its exchange rate inside this negotiated zone. Each time the exchange rate got out of the band this member would have to consult with affected countries in the WTO.

5 - The remedies available could be multilateral, such as raising or cutting tariffs for all the sectors, or bilateral, as currency anti-subsidies or currency safeguards for affected sectors after examination of injury between the parts affected.

The idea is to create an objective criterion to allow the neutralization of the effects derived from misalignments on trade instruments. The main goal is to develop this exercise using the principles, rules and instruments of the WTO, that is, under the logic of the WTO.

\section{A first simulation: the WTO Box of Snakes}

In order to center the discussion on WTO rules and instruments, a methodology was developed to create a box or a target zone for currency fluctuations.

\section{i. Estimation of exchange rate fluctuations against a virtual world currency}

A methodology is here presented to construct a band to limit the degree of exchange rate misalignments.

The challenge is to create a world currency to evaluate the fluctuations of each singular currency against this world currency and use these deviations to neutralize the effects of exchange misalignments on trade instruments.

One approach is based on PPP — Purchasing Power Parity, one of the simplest concepts of Economics - the Law of One Price. Following this Law, on the long run, all 
prices will be equal, translated by the exchange rate of each country. This simple approach is explored, inter alia, in the Big Mac Index, estimated by the magazine The Economist.

There is a debate on the validity of PPP theory in the literature. However, there has been a revival of this approach after new estimates based on very long periods of time (Alan Taylor, The Purchaising Power Debate, JEP, 2004).

\section{ii. World price index and world currency index}

The methodology to construct the World Price Index and the World Currency Index, both inputs to calculate the PPP index based on world indexes uses the relative PPP approach. This approach states that the rate of appreciation/depreciation of a currency is equal to the difference in inflation rates between home and foreign country (in our case, the World Index). If the equality does not hold, there is an indication that the currency is overvalued or undervalued against the World Currency Index. An increasing PPP indicates that the country's currency is overvalued and losing competitiveness and a decreasing PPP shows the inverse relation.

The first step is to construct the indexes. Twenty countries ${ }^{3}$ were selected with the biggest shares in world trade (exports plus imports) ${ }^{4}$. Using the trade data of each country, the weight of each country in the selected basket for each period can be calculated. The weight of the country in the basket at the time can be expressed as:

$$
W_{i t}=\frac{\text { Imports }_{i t}+\text { Exports }_{i t}}{\sum_{i=1}^{N}\left(\text { Imports }_{i t}+\text { Exports }_{i t}\right)}
$$

The second step is to calculate the World Price Index, using the Consumer Price Index of each country in the basket. The World Price Index can be defined as ${ }^{5}$ :

$$
W P I_{t}=\sum_{i=1}^{N} X_{i t} C P I_{i t}
$$

The third step is to use the same idea to construct the World Currency Index. Given, the exchange rate (national currency per US dollar) of the country at the time, the index is defined $b y^{6}$ :

\footnotetext{
${ }^{3}$ To calculate the indexes the following countries were selected: Australia, Austria, Belgium, Brazil, Canada, China, France, Germany, India, Italy, Japan, Korea, Malaysia, Mexico, Netherlands, Spain, Sweden, Switzerland, United Kingdom and United States. Due to lack of data, we couldn't add: Czech Republic, Hong Kong, Indonesia, Poland, Singapore, Russia, Thailand and Turkey. OPEC countries: Saudi Arabia and United Arab Emirates were also not considered

${ }^{4}$ Source: IMF, Annual Frequency.

${ }^{5}$ The CPI indexes are available at IFS/IMF database, Monthly Frequency. Jan-2000 $=100$.

${ }^{6}$ The exchange rates are also available at IFS/IMG database, Monthly Frequency. They have been normalized to Jan-2000 $=1$.
} 


$$
\mathrm{WCI}_{t}=\sum_{i=1}^{N} X_{i t} e_{i t}
$$

The forth step is, after estimating WPI and WCI, to calculate the Purchasing Power Parity, for the country at the time, as given by:

$$
P P P_{i t}^{W C I}=\frac{C P I_{i t}}{W P I_{t}} \frac{W C I_{t}}{e_{i t}}
$$

After this, PPPs were normalized for Jan-2000=100.

Finally all the series were adjusted to have mean equals to zero and variance equals to one. The Graphic 10 presented the results of the estimation. Variations of each currency were presented in a box defined by one or two standard deviations, implying that the box can capture $60 \%$ or $95 \%$ of the exchange rate misalignments.

As depicted in the graphic, a threshold band defined by + or - one standard deviation (ex. a variation of $10 \%$ ), many countries would have to consult in the WTO. For a threshold band defined by + or - two standard deviations (ex. a variation of $20 \%$ ), only a few members would be considered. A reasonable solution would be somewhere between one and two standard deviations (ex. a variation of $15 \%)$. The results are presented below:

\section{Graphic 10: The WTO Box of Snakes — for 7 countries}

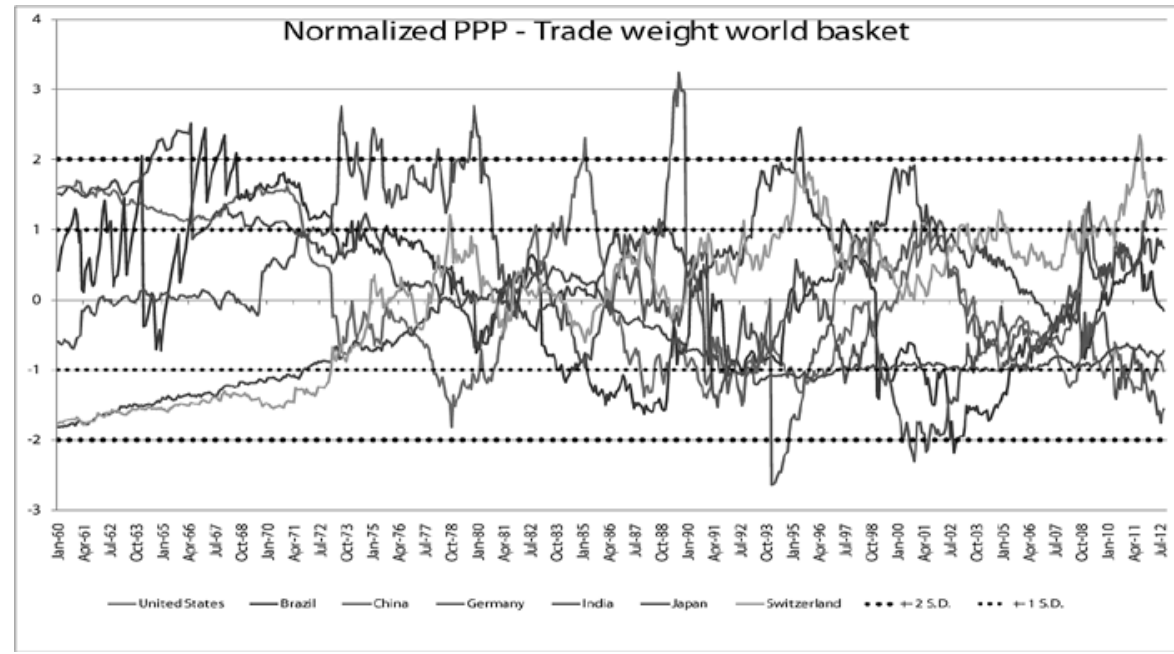

Source: Observatory on Exchange Rate (2013). 


\section{FINAL CONCLUSIONS}

The issue of exchange rate misalignments is already in the news as currency wars menace, leading to trade wars. This discussion is being held not only at the G20, but also at the IMF and at the WTO.

The real problem is how the significance and persistence of these misalignments are distorting not only trade rules but also financial rules. In other words, whether exchange rate misalignments are affecting the objectives of trade and financial policies and neutralizing the efficiency of their instruments.

The origin of the problem can be traced back to the creation of the Bretton Woods System in the 1940's with the functional distinction between the GATT and the IMF. The GATT was created to be responsible only for trade and the IMF for exchange rates and balance of payments practices. At the time, the system worked under the dollar/gold standard regime. However, even after the implosion of this system, only the IMF was adapted to face different exchange rate regimes. The GATT and the WTO remained silent and paralyzed facing this revolution, expecting that the trade system could survive this tectonic shift.

With the advent of China in the international arena, as a new economic power and the world's biggest exporter of goods, and its influence on the currency of almost all ASEAN area countries, the exchange rate issue has been globalized. The successive monetary expansion of the U.S. (QEs) and later UE and Japan are affecting directly the international trade policy of all trade partners. For the WTO, the only rule linking trade and exchange rate, since 1947, has been GATT Article $\mathrm{XV}$.

No member has ever had the initiative to contest the practice of another member under this article. To solve the issue, several proposals for the use of trade remedies, such as anti-dumping and countervailing measures to offset the exchange rate effects have been discussed ${ }^{7}$. But again, no member has so far applied them as an instrument to neutralize the use of exchange rates as unfair trade, although there is already some discussion in the U.S.' Congress.

Considering the extent and persistence of last couple of years' exchange rate misalignments, and their effects on trade, pressure is mounting for the negotiation of some kind of solution. Discussions were held in the G20, the IMF and the WTO, but nothing has yet been achieved.

Nowadays, economists are consolidating an important academic production indicating the extent of the problem.

These studies present different methodologies and a great variety of results because they have different objectives. For the WTO, the perfect accuracy of the exchange rates misalignment estimates is not relevant. The main point is to find out a threshold, a limit of a band of fluctuation, from where trade policy instruments

\footnotetext{
${ }^{7}$ See Lima-Campos, A.; Gil, J. A. Gaviria, "A case for misalingned currencies as countervailable subsidies”, Journal of World Trade, vol. 46, issue. 4, 2012.
} 
become ineffective. This happens when the impacts of exchange rates nullify the efficacy of the rules negotiated in the trading system over the last six decades.

The results presented in this paper on the effects of exchange on tariffs are evident and strong:

- Countries with undervalued exchange rates, depending on the level of such depreciation, can have their bound and applied tariffs being increased in greater proportions than the notified tariffs. For countries with a small difference between applied and bound tariffs, any depreciation may imply that applied tariffs surpass the limits negotiated within the WTO. Considering the cumulative effects of misalignments, each importing country will offer different market accesses to different exporter country violating GATT Article I.

- Countries with overvalued exchange rates, depending on the level of such appreciation, can have their bound and applied tariffs reduced or nullified to negative levels, implying that the country is granting a stimulus to imports and waiving the tariff protection level negotiated within the WTO.

Against the reality of exchange rate misalignments, it is time to start negotiating a mechanism to neutralize exchange rate effects on tariffs and other trade instruments, which will allow the maintenance of the level of market access previously established.

WTO is facing a serious identity crises. Without the neutralization of the effects of misalignments on WTO rules and instruments, WTO is a strong juridical construction with a weak economic basis. WTO should not wait for a new Bretton Woods to be relevant again. It should take the front of trade regulation again and lead the reform of the multilateral economic system!

\section{REFERENCES}

Alberola, E., S. Cervero, et al. (1999) “Global Equilibrium exchange rate: Euro, Dolar, 'Ins', ‘Outs' and other major currencies in a Panel Cointegration Framework”. IMF Working Paper. Washington: IMF. 99-175.

Bergsten, F.,Gagnon, J., (2012) “Currency Manipulation, the US Economy, and the Global Economic Order” (PB12-25), Peterson Institute, Washington.

Cline, W. R. (2008) "Estimating consistent fundamental equilibrium exchange rate". Working paper Series. Washington: Peterson Institute for International Economics.

Cline, W; Williamson, J., (2012) Estimates of Fundamental Equilibrium Exchange Rates, Peterson Institute, May 2011, May 2012, Update - Nov. 2012.

Dornbusch, R. (1976) “Expectations and Exchange Rate Dynamics”. Journal of Political Economy, v.84, n.6, p.1161-1176.

Engle, R. F. and C. W. J. Granger. (1987) "Co-integration and Error Correction: Representation, Estimation and Testing". Econometrica, v.55, p.251-276.

Faruqee, H. (1995) "Long-run determinants of the real exchange rate: A stock Flow Perspective". IMF Staff Paper, v.42, p.80-107.

Fudge, N. (2011) "Walter Mitty and the Dragon: An Analysis of the Possibility for WTO or IMF Action against China's Manipulation of the Yuan”, Journal of World Trade 45, no. 2, p. 349-373.

Gagnon, J., (2012) Combating Widespread Currency Manipulation, (Policy Briefs in international Economics 12-19), Peterson Institute, Washington. 
Gonzalo, J. e C. W. J. Granger. (1995) "Estimation of Common Long-Memory Components in Cointegrated Systems". Journal of Business and Economics Statistics, v.13, n.1. 1995.

Irwin, D.A., (2011) “Sprit de Currency”, Finance and Development, Vol. 48, No 2, IMF, June.

Johansen, S. (1995) Likelihood-based inference in cointegrated vector autoregressive models. Oxford: Oxford University Press. x, 267 p. (Advanced texts in econometrics)

Kubota, M. (2009) "Real Exchange Rate Misalignments: Theoretical modelling and empirical evidence". Discussion Papers in Economics. York: University of York.

Lima-Campos, A.; Gil, J. A. Gaviria, (2012) "A case for misalingned currencies as countervailable subsidies", Journal of World Trade, v. 46, i. 4.

Marçal, E., (2012) "O mistério da taxa de câmbio real chinesa: algumas razões que podem explicar a diversidade dos resultados”, Itexto p[ara discussão 1969, IPEA.

Meese, R. A. and K. Rogoff. (1983) "Empirical Exchange models of the seventies: Do they fi out of the sample?" Journal of International Economics, v.14, p.3-24.

Mussa, M. (1976) "The exchange rate, the balance of payments and monetary policy under a regime of controlled floating”. Scadinavian Journal of Economics, v.78, p.228-248.

Stein, J. (1995) "The Fundamental Determinants of the Real Exchange Rate of the U.S. Dollar Relative to Other G-7 Currencies”. IMF Working Paper, v.95-81.

Taylor, A.T. and Taylor, M.P. (2004) “The purchasing power parity debate”. Journal of Economic Perspectives, n. 18, (4) p.135-158.

Thorstensen, V; Marçal, E.; Ferraz, L.; (2012) "Impacts of Exchange Rates on International Trade Policy Instruments: The Case of Tariffs", Journal of World Trade, v. 46, i. 3.

Zimmermann, C. D. (2011) “Exchange Rate Misalignment and International Law", vol 105(3) the American Journal of International Law, p.423-476. 